\title{
The application of resveratrol to mesenchymal stromal cell-based regenerative medicine
}

\author{
Chenxia Hu and Lanjuan Li
}

\begin{abstract}
Currently, the transplantation of mesenchymal stromal cells (MSCs) has emerged as an effective strategy to protect against tissue and organ injury. MSC transplantation also serves as a promising therapy for regenerative medicine, while poor engraftment and limited survival rates are major obstacles for its clinical application. Although multiple studies have focused on investigating chemicals to improve MSC stemness and differentiation in vitro and in vivo, there is still a shortage of effective and safe agents for MSC-based regenerative medicine. Resveratrol (RSV), a nonflavonoid polyphenol phytoalexin with a stilbene structure, was first identified in the root extract of white hellebore and is also found in the roots of Polygonum cuspidatum, and it is widely used in traditional Chinese medicine. RSV is a natural agent that possesses great therapeutic potential for protecting against acute or chronic injury in multiple tissues as a result of its antioxidative, anti-inflammatory, and anti-cancer properties. According to its demonstrated properties, RSV may improve the therapeutic effects of MSCs via enhancing their survival, selfrenewal, lineage commitment, and anti-aging effects. In this review, we concluded that RSV significantly improved the preventive and therapeutic effects of MSCs against multiple diseases. We also described the underlying mechanisms of the effects of RSV on the survival, self-renewal, and lineage commitment of MSCs in vitro and in vivo. Upon further clarification of the potential mechanisms of the effects of RSV on MSC-based therapy, MSCs may be able to be more widely used in regenerative medicine to promote recovery from tissue injury.
\end{abstract}

\section{Introduction}

The transplantation of mesenchymal stromal cells (MSCs) has emerged as an effective strategy to protect against tissue and organ injury. According to the ISCT criteria, MSCs must have multipotency to differentiate into somatic cells, including osteocytes, adipose cells, and chondrocytes [1]. MSCs with multilineage potential exist prevalently in almost all tissues, and they are promising cell sources for treating multiple diseases without ethical issues [2]. After transplantation in vivo, MSCs exert proangiogenic, anti-apoptotic, and antioxidative effects on host tissues and activate local quiescent stem cells to establish cellular interactions by autocrine and paracrine pathways [3]. MSCs are capable of modulating the innate immune system and influencing the functions of $\mathrm{T}$ and $\mathrm{B}$

\footnotetext{
* Correspondence: |jli@zju.edu.cn

Collaborative Innovation Center for the Diagnosis and Treatment of Infectious Diseases, State Key Laboratory for the Diagnosis and Treatment of Infectious Diseases, First Affiliated Hospital, School of Medicine, Zhejiang University, Hangzhou 310000, People's Republic of China
}

cells, including regulatory cells, along with influencing Th1 and Th2 cell differentiation [4-6]. Other advantages of MSCs are their immune privilege and relative safety when used in allogeneic hosts [4]. In addition, homotypic and heterotypic cell fusions of MSCs, although rare, also contribute to the repair of tissues [7]. MSC transplantation also serves as a promising therapy for regenerative medicine, but poor engraftment and limited survival rates are major obstacles to its clinical application. Although multiple studies have focused on investigating chemicals to improve MSC stemness and differentiation in vitro and in vivo, there is still a shortage of effective and safe agents for MSC-based regenerative medicine.

Resveratrol (RSV), a nonflavonoid polyphenol phytoalexin with a stilbene structure, was first found in the root extract of white hellebore (Veratum grandiflorum) and was also found in the roots of Polygonum cupsidatum in 1963, and it is widely used in traditional Chinese medicine [8]. A large amount of RSV can be found in multiple

(c) The Author(s). 2019 Open Access This article is distributed under the terms of the Creative Commons Attribution 4.0 International License (http://creativecommons.org/licenses/by/4.0/), which permits unrestricted use, distribution, and 
plants, including peanuts, eucalyptus, blueberries, cranberries, and grapes [9]. Cis-RSV is an unstable and less common compound, while trans-RSV is the stable form and is more predominant; trans-RSV can be converted to cis-RSV after exposure to sunlight or UV radiation [10]. RSV effectively inhibits the generation of reactive oxygen species (ROS)/reactive nitrogen species (RNS) and scavenges excessive ROS/RNS mainly through synergistic effects between the 4-hydroxyl group, 3-hydroxyl group, and 5-hydroxyl group [11]. In addition, RSV significantly enhances the interaction between lamin A and SIRT1 [12], which is a member of a family of $\mathrm{NAD}^{1}$-dependent deacetylases that participate in the modulation of apoptosis, DNA repair, oxidative stress resistance, anti-aging processes, and lipid metabolism [13]. Several derivatives, such as methoxylated, hydroxylated, and halogenated forms of RSV, have been developed for diverse therapeutic applications [14]. Moreover, RSV is a natural agent that possesses a wide therapeutic potential as a result of its antioxidative [15], anti-inflammatory [16], and anti-cancer [17] properties for the protection of multiple tissues against acute or chronic injury. According to its demonstrated properties, RSV may improve the therapeutic effects of MSCs by enhancing their survival, self-renewal, lineage commitment, and anti-aging effects.

In this review, we concluded that RSV significantly improved the preventive and therapeutic effects of MSCs against multiple diseases. We also describe the underlying mechanisms of the effects of RSV on the survival, self-renewal, and lineage commitment of MSCs in vitro and in vivo (Fig. 1). We showed that the use of the optimal dose of RSV may contribute greatly to MSCbased regenerative medicine.

\section{The administration and bioactivity of RSV}

In general, people receive RSV via oral administration and intravenous administration, and the major route of RSV administration is oral intake. Due to its lipophilic features, RSV can be dissolved in alcoholic solutions, fruit juices, or vegetable juices or placed in capsules [18, 19].

Interestingly, RSV attracted the attention of many scientists because of a special phenomenon called the "French paradox" [15]. Despite the high-fat consumption of the French population, they have a low incidence of cardiovascular diseases since they frequently drink RSVcontaining wine. A total of $50-100 \mathrm{mg} / \mathrm{g}$ of RSV exists in fresh grape skins, and approximately $0.2-5.8 \mathrm{mg} / \mathrm{L}$ of RSV exists in wine depending on the kind of wine [15]. After oral consumption, RSV is rapidly absorbed, and the plasma RSV concentration peaks at $30 \mathrm{~min}$. Approximately $70-75 \%$ of the absorption occurs through transepithelial diffusion [20]. Since RSV is mainly metabolized in the intestine and liver through glucuronidation and sulfation, RSV bioavailability is highly reduced in vivo [21]. Although RSV has a high oral absorbance after digestion, its bioavailability is quite low due to its rapid metabolism [22, 23]. RSV is present as piceid in dietary

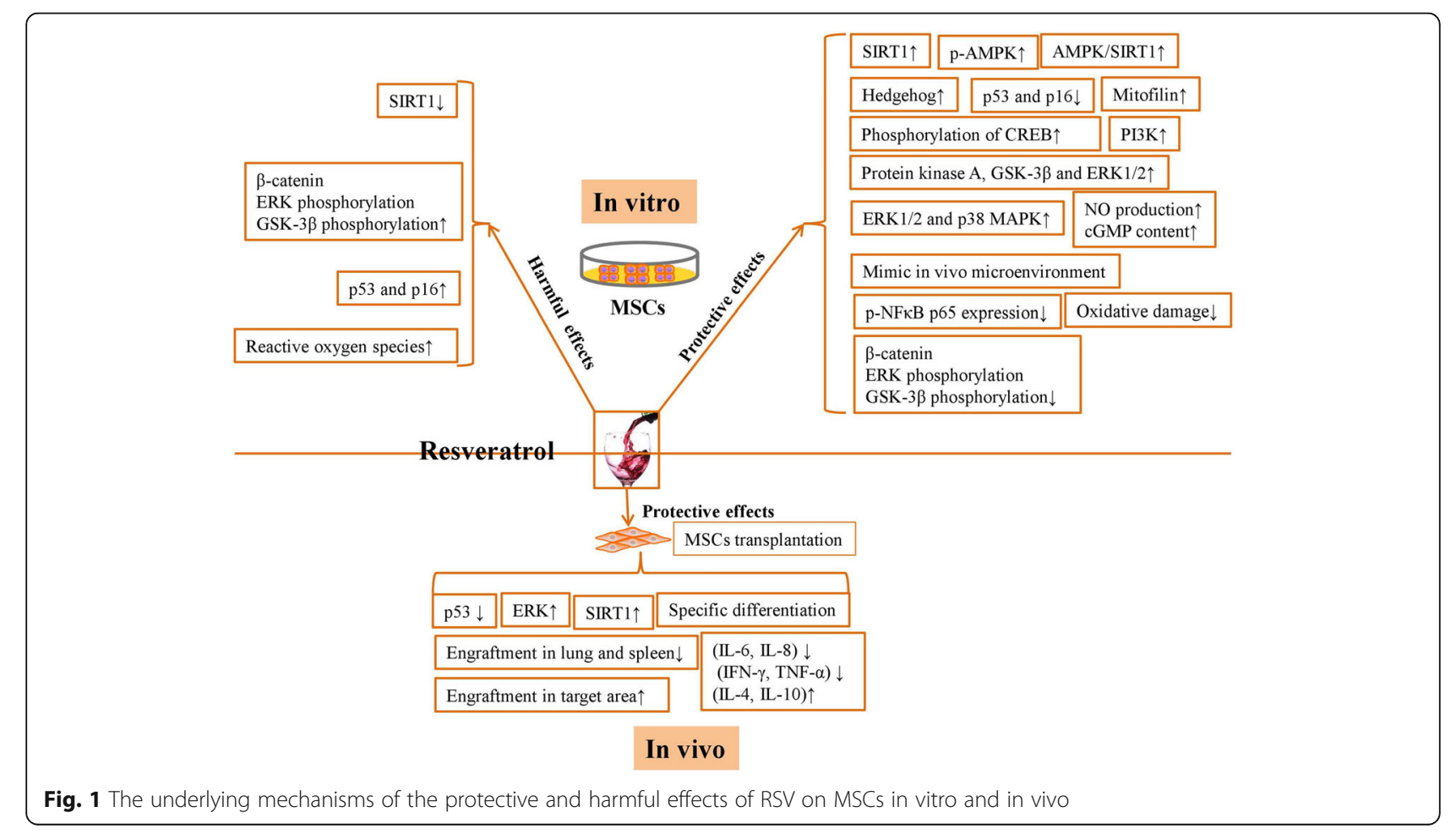


products and can be metabolized by polyphenol oxidation, while glycosylation prevents the enzymatic oxidation of RSV and maintains its biological stability and bioavailability [24]. Thus, it is necessary to improve the bioavailability of RSV for MSC-based regenerative medicine.

Various RSV derivatives, such as prodrugs and synthetic analogs, have been developed to improve the bioavailability of RSV in vivo via the regulation of absorption, distribution, metabolism, and excretion and to ensure its biological and pharmacological activity without cytoxicity $[25,26]$. In addition, other studies have proposed the use of different carriers to deliver increased levels of RSV into targeted tissues by improving the solubility, stability, permeability, and release of RSV in vivo [27]. Nanoformulations of RSV significantly enhance the absorption of RSV and protect it from the metabolism in animal models, and nanoparticle formulation was shown to ensure increased distribution in tissues such as the liver, heart, kidney, and ovary than more common methods of RSV administration [28]. However, most studies have used RSV but not RSV derivatives to improve the therapeutic effects of MSCs, and the optimization of delivery systems for RSV is more important for current MSC-based regenerative medicine. Thus, various delivery systems, including lipid nanocarriers, emulsions, micelles, polymeric nanoparticles, solid dispersions, and nanocrystals, have been developed for RSV encapsulation. These delivery systems protect RSV against degradation and ensure the sustained release of RSV. Lipid nanocarriers decreased the gastrointestinal damage of RSV and also improved the concentration and bioavailability of RSV in the brain, liver, and kidney of rats [29]. Subcellular-sized nanoemulsion systems also protect against chemical degradation and oxidation and then convert RSV into its cis-form [30]. Micellar solutions of bile acids that contained 3,7,12-triketocholic acids showed the smallest membranolytic potential, and they more effectively solubilized RSV and improved its resorption [31]. To further improve the oral bioavailability of RSV, polymeric nanoparticles that slowly degrade in vivo have been recognized as a more suitable oral delivery system than other rapidly degradable nanoparticles and nondegradable nanoparticles [32]. Recently, Chang et al. found that the easy manipulation and powdered form of solid dispersion drug delivery systems enhanced the solubility, dissolution, and absorption of RSV [33]. Moreover, nanoparticles could also be used to deliver RSV nanocrystals to further improve the solubility, dissolution rate, stability, compatibility, and oral bioavailability of RSV [34]. On the other hand, the intravenous administration of RSV completely bypassed gastrointestinal absorption and delivered RSV directly into serum to maximize the bioactivity of RSV. In comparison with oral administration, the intravenous administration of RSV and its metabolites led to a higher serum area under the curve in rats [35]. However, there are still no effective methods that can completely protect the bioactivity of RSV in vivo.

\section{In vitro effects of RSV on MSCs}

To acquire a sufficient number of MSCs, MSCs are cultured ex vivo with animal serum and various growth factors; thus, we believe that repeated freezing/thawing, ex vivo culture conditions, and successive passaging are deleterious to MSCs and render them more susceptible to the microenvironment $[36,37]$. The oxygen concentration of cultured MSCs in vitro $\left(20-21 \% \mathrm{O}_{2}\right)$ is higher than that (i.e., $1-5 \% \mathrm{O}_{2}$ ) encountered by MSCs tissues [38], and the difference in the surrounding oxygen concentration will consequently decrease the proliferation, differentiation, and anti-inflammatory effects of MSCs $[39,40]$. RSV has been shown to protect MSCs from senescence and aging; moreover, RSV also participates in the regulation of the osteogenesis, adipogenesis, and neurogenesis of MSCs in vitro (Table 1).

\section{The effects of RSV on MSC senescence and aging}

Long-term in vitro cultures may lead to cell aging in MSCs accompanied by decreased self-renewal, increased cell senescence, upregulated cell apoptosis, and premature differentiation, consequently decreasing the therapeutic effects of MSCs in vivo. Pretreatment with RSV inhibited radiation-induced IL-1 $\beta$ expression by activating SIRT1 in a concentration-dependent manner, thus protecting cells against radiation-induced injury [41]. In contrast, there is a debate regarding the protective effects of RSV on aging and senescence in MSCs under other specific conditions. Although RSV effectively improved the self-renewal potential and multipotency of early passage MSCs via activating SIRT1 and decreasing $\beta$-catenin activity, ERK phosphorylation, and GSK-3 $\beta$ phosphorylation, it significantly increased the cellular senescence in late passage MSCs via the abrogation of the above pathways [42]. At concentrations of $0.1,1$, and $2.5 \mu \mathrm{M}$, RSV increased SIRT1 levels while inhibiting the expression of $\mathrm{p} 53$ and $\mathrm{p} 16$, thus promoting cell viability and mitigating the senescence of MSCs. RSV at concentrations of 5 and $10 \mu \mathrm{M}$ increased the levels of senescence and apoptosis via inhibiting SIRT1 and PCNA and stimulating the expression of p53 and p16 [43]. A high dose of RSV $(60 \mu \mathrm{M})$ is able to protect quiescent MSCs from oxidative damage and trigger the reversible blockage of cell proliferation without genotoxic effects, but this results in irreversible cell cycle arrest, DNA damage, and premature senescence in proliferating MSCs [44]. Although multiple studies have shown the protective 
Table 1 Various concentrations of RSV exert different effects on MSCs in vitro

\begin{tabular}{|c|c|c|c|c|c|}
\hline RSV concentration & MSC source & Matrix & Mechanism & Effect & Reference \\
\hline $200 \mu \mathrm{M}$ & $\begin{array}{l}\text { Umbilical cord } \\
\text { blood }\end{array}$ & N/A & Activate SIRT1 & $\begin{array}{l}\text { Attenuate IL-1 } \beta \text { and NLRP3 } \\
\text { expression induced by radiation }\end{array}$ & [41] \\
\hline $1 \mu \mathrm{M}$ & Bone marrow & N/A & 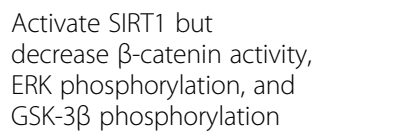 & $\begin{array}{l}\text { Improve the self-renewal potential } \\
\text { and multipotency of early passage } \\
\text { MSCs }\end{array}$ & [42] \\
\hline $1 \mu \mathrm{M}$ & Bone marrow & N/A & $\begin{array}{l}\text { Decrease SIRT1 but } \\
\text { increase } \beta \text {-catenin activity, } \\
\text { ERK phosphorylation, and } \\
\text { GSK-3 } \beta \text { phosphorylation }\end{array}$ & $\begin{array}{l}\text { Increase cellular senescence in late } \\
\text { passage MSCs }\end{array}$ & {$[42]$} \\
\hline $0.1,1$, and $2.5 \mu \mathrm{M}$ & Umbilical cord & N/A & $\begin{array}{l}\text { Increase SIRT1 level while } \\
\text { inhibiting the expression } \\
\text { of p53 and p } 16\end{array}$ & $\begin{array}{l}\text { Promote cell viability and mitigate } \\
\text { the senescence of MSCs }\end{array}$ & [43] \\
\hline 5 and $10 \mu \mathrm{M}$ & Umbilical cord & N/A & $\begin{array}{l}\text { Inhibit SIRT1 and PCNA } \\
\text { and stimulate the } \\
\text { expression of p53 and p16 }\end{array}$ & $\begin{array}{l}\text { Increase the levels of senescence } \\
\text { and apoptosis in MSCs }\end{array}$ & [43] \\
\hline $60 \mu \mathrm{M}$ & Menstrual blood & N/A & $\begin{array}{l}\text { Reduce oxidative damage in } \\
\text { quiescent MSCs and maintain } \\
\text { physiological levels of } \\
\text { reactive oxygen species in } \\
\text { proliferating cells }\end{array}$ & $\begin{array}{l}\text { Induce the reversible blockage of } \\
\text { cell proliferation without genotoxic } \\
\text { effects in quiescent MSCs and induce } \\
\text { irreversible cell cycle arrest, DNA } \\
\text { damage, and premature senescence } \\
\text { in proliferating MSCs }\end{array}$ & [44] \\
\hline $10(-8)-10(-6) \mathrm{M}$ & Bone marrow & N/A & $\begin{array}{l}\text { Increase NO production and } \\
\text { CGMP content }\end{array}$ & $\begin{array}{l}\text { Increase cell growth and the } \\
\text { osteogenic differentiation of MSCs }\end{array}$ & [45] \\
\hline $10^{-6} \mathrm{M}$ & Bone marrow & N/A & Activate ERK $1 / 2$ and p38 MAPK & $\begin{array}{l}\text { Increase cell growth and the } \\
\text { osteogenic differentiation of MSCs }\end{array}$ & [46] \\
\hline $25 \mu \mathrm{M}$ & Adipose tissue & $\begin{array}{l}\text { Collagen-containing } \\
\text { RSV scaffolds }\end{array}$ & Mimic in vivo microenvironment & $\begin{array}{l}\text { Increase the level of mineralized } \\
\text { matrix in the continuously treated } \\
\text { group }\end{array}$ & [47] \\
\hline $50 \mu \mathrm{M}$ & Adipose tissue & $\begin{array}{l}\text { Collagen-containing } \\
\text { RSV scaffolds }\end{array}$ & $\begin{array}{l}\text { Enhance the epithelial and } \\
\text { osteogenic differentiation of } \\
\text { MSCs }\end{array}$ & Repair defects in calvarial bone & [48] \\
\hline $10 \mu \mathrm{M}$ & Bone marrow & N/A & $\begin{array}{l}\text { Upregulate the expression of } \\
\text { mitofilin }\end{array}$ & $\begin{array}{l}\text { Improve the osteogenic } \\
\text { differentiation of senescent MSCS }\end{array}$ & [49] \\
\hline $10 \mathrm{nM}$ & $\begin{array}{l}\text { Periodontal } \\
\text { ligament }\end{array}$ & N/A & $\begin{array}{l}\text { Decrease p-NFkB p65 expression } \\
\text { and rescue the p-AMPK level }\end{array}$ & $\begin{array}{l}\text { Rescue the impairment of } \\
\text { osteogenesis and regeneration in } \\
\text { MSCs from periodontitis patients } \\
\text { and normal MSCs treated with } \\
\text { TNF-a }\end{array}$ & {$[50]$} \\
\hline $1 \mu \mathrm{M}$ & Bone marrow & N/A & Upregulate hedgehog signaling & $\begin{array}{l}\text { Reduce free radical production and } \\
\text { protect against CSE-induced injury }\end{array}$ & [51] \\
\hline $25 \mu \mathrm{M}$ & Bone marrow & N/A & $\begin{array}{l}\text { Substitute for insulin in adipogenic } \\
\text { medium and enhance the } \\
\text { phosphorylation of cyclic AMP } \\
\text { response element-binding protein } \\
\text { (CREB) }\end{array}$ & $\begin{array}{l}\text { Induce the robust adipogenesis of } \\
\text { MSCs }\end{array}$ & {$[52]$} \\
\hline $1 \mu \mathrm{M}$ & Bone marrow & N/A & N/A & $\begin{array}{l}\text { Increase the expression of neuronal } \\
\text { marker proteins and the number } \\
\text { and length of neurites }\end{array}$ & [53] \\
\hline $2.5,5$, and $10 \mu \mathrm{M}$ & Umbilical cord & N/A & $\begin{array}{l}\text { Reduce the expression of nestin } \\
\text { while upregulating the expression } \\
\text { of } \beta \text { III-tubulin and NSE in a dose- } \\
\text { dependent manner and enhance } \\
\text { the expression of neurogenin } 1 \text { and } \\
2 \text { as well as Mash1 }\end{array}$ & $\begin{array}{l}\text { Increase the neuronal differentiation } \\
\text { of MSCs }\end{array}$ & [43] \\
\hline $10 \mu \mathrm{M}$ & Cord blood & N/A & $\begin{array}{l}\text { Increase the levels of protein } \\
\text { kinase A, GSK-3 } 3 \text {, and ERK1/2 }\end{array}$ & $\begin{array}{l}\text { Enhance the phosphorylation of CREB } \\
\text { and increase the expression of neural } \\
\text { markers }\end{array}$ & [54] \\
\hline $15 \mu \mathrm{M}$ & Dental pulp & N/A & Increase the expression of the & Promote the neuronal cell differentiation & [55] \\
\hline
\end{tabular}


Table 1 Various concentrations of RSV exert different effects on MSCs in vitro (Continued)

\begin{tabular}{|c|c|c|c|c|c|}
\hline RSV concentration & MSC source & Matrix & Mechanism & Effect & Reference \\
\hline & & & $\begin{array}{l}\text { neuronal-specific marker genes } \\
\text { nestin, musashi, and NF-M in } \\
\text { MSCs }\end{array}$ & of MSCs & \\
\hline 15.0 and $30.0 \mathrm{mg} / \mathrm{L}$ & Umbilical cord & N/A & N/A & $\begin{array}{l}\text { Induce the differentiation of } \\
\text { hUC-MSCs into neuron-like cells }\end{array}$ & {$[56]$} \\
\hline $1 \mu \mathrm{M}$ & Bone marrow & N/A & $\begin{array}{l}\text { Upregulate AMPK/SIRT1 } \\
\text { signaling }\end{array}$ & $\begin{array}{l}\text { Increase the levels of neuroprogenitor } \\
\text { markers in MSCs isolated from ALS } \\
\text { patients }\end{array}$ & {$[57]$} \\
\hline $10 \mu \mathrm{M}$ & Cord blood & N/A & $\begin{array}{l}\text { Activate the PI3K signaling } \\
\text { pathway }\end{array}$ & $\begin{array}{l}\text { Restore the impaired neuronal } \\
\text { differentiation ability of MSCs induced } \\
\text { by the neurotoxic organophosphate } \\
\text { pesticide monocrotophos }\end{array}$ & {$[58]$} \\
\hline $10 \mu \mathrm{M}$ & Cord blood & N/A & $\begin{array}{l}\text { Activate the PI3K-mediated } \\
\text { pathway }\end{array}$ & $\begin{array}{l}\text { Repair monocrotophos-induced } \\
\text { damage and protect against } \\
\text { organophosphate pesticide-induced } \\
\text { neurodegeneration }\end{array}$ & {$[58]$} \\
\hline
\end{tabular}

effects of RSV, RSV will also exert cytotoxic effects on proliferating MSCs in vitro, which will lead to cell death.

\section{The effects of RSV on the osteogenic differentiation and adipogenic differentiation of MSCs}

The use of RSV (10(-8)-10(-6) M) resulted in a dosedependent increase in the growth and osteogenic differentiation of MSCs by increasing NO production and cGMP content [45] and activating ER-mediated extracellular signal-regulated kinase $1 / 2($ ERK1/2) [46]. MSCs showed good adherence to collagen-containing RSV (collagen/RSV) scaffolds, and pretreatment with $25 \mu \mathrm{M}$ RSV for a short time increased the amount of mineralized matrix in the continuously treated group [47]. In addition, MSCs cultured on collagen/RSV scaffolds demonstrated a higher proliferation rate than those cultured on collagen scaffolds. Defects in the calvarial bone could be repaired more effectively by MSCs on collagen/RSV scaffolds than by MSCs on collagen scaffolds [48].

In addition to normal MSCs, RSV can upregulate the osteogenic differentiation of MSCs in some pathological conditions. RSV significantly upregulated the expression of mitofilin, which is the core component of the mitochondrial contact site and cristae organizing system (MICOS), and then enhanced the osteogenic differentiation of senescent MSCs in vitro [49]. RSV rescued the impairment of osteogenesis and regeneration in MSCs from periodontitis patients and in normal MSCs treated with TNF- $\alpha$ [50]. Cigarette smoke extract (CSE) impaired the primary cilia distribution and osteogenic differentiation of MSCs via downregulating hedgehog signaling, while $1 \mu \mathrm{M}$ RSV significantly reduced free radical production and protected against CSE-induced injury [51].

In addition, $1 \mu \mathrm{M}$ RSV enhanced the adipogenic or osteogenic differentiation, and $25 \mu \mathrm{M}$ RSV resulted in the robust adipogenesis of MSCs upon substitution for insulin in adipogenic medium and enhanced the phosphorylation of cyclic AMP response element-binding protein (CREB) [52].

Therefore, RSV may participate in the regulation of osteogenesis and adipogenesis of MSCs in vitro, as this indicates that the number and quality of studies about the effects of RSV on the adipogenesis of MSCs should be improved. RSV may act as an antioxidant or nutritional compound during the differentiation process, and its specific effects should be further determined according to its concentration.

\section{The effects of RSV on the neural differentiation of MSCs}

Recent studies have demonstrated that RSV concentrations within a wide range are safe and able to promote MSC neurogenesis in vitro. Although untreated MSCs and MSCs pretreated with $1 \mu \mathrm{M}$ RSV exhibited similar morphology to the neurons after culture in neuronal induction media, the RSV-pretreated MSCs showed a significant increase in the expression of neuronal marker proteins and the number and length of neurites when compared with untreated MSCs [53]. At concentrations of $2.5,5$, and $10 \mu \mathrm{M}$, RSV increased the neuronal differentiation of human MSCs in a dose-dependent manner via reducing the expression of nestin and upregulating the expression of $\beta$ III-tubulin, NSE, neurogenin, and mash1 [43]. A concentration of $10 \mu \mathrm{M}$ RSV alone or in combination with nerve growth factor enhanced the phosphorylation of CREB and increased the expression of neural markers via the activation of protein kinase $A$, GSK-3 $\beta$, and ERK1/2 [54]. RSV $(15 \mu \mathrm{M})$ increased the expression of neuron-specific marker genes such as nestin, musashi, and NF-M in MSCs, thus promoting the neuronal cell differentiation of MSCs [55]. Intriguingly, Guo et al. demonstrated that a high dose of 
RSV (30 mg/L) exerted no negative effect on GFAP and glial markers in MSCs and also significantly induced the differentiation of MSCs into neuron-like cells [56].

MSCs from amyotrophic lateral sclerosis (ALS) patients have functional limitations in terms of the release of neurotrophic factors and exhibit a senescent phenotype. Pretreatment with $1 \mu \mathrm{M}$ RSV increased the levels of neuroprogenitor markers in MSCs isolated from ALS patients via the upregulation of AMPK/SIRT1 signaling. The differentiated ALS-derived MSCs exhibited a cell body and dendritic shape similar to neurons [57]. RSV at $10 \mu \mathrm{M}$ successfully restored the alterations of MSCs and rescued the impaired neuronal differentiation ability of MSCs induced by the neurotoxic organophosphate pesticide monocrotophos [58]. Moreover, $10 \mu \mathrm{M}$ RSV repaired monocrotophosinduced damage via the PI3K-mediated pathway and promoted the neuronal differentiation of MSCs, thus indicating potential protection by RSV against organophosphate pesticide-induced neurodegeneration [58].

\section{The effects of RSV on MSCs in vivo}

A harsh microenvironment in vivo induces MSCs to undergo senescence or apoptosis, thus impairing the balance between ROS and antioxidant mechanisms and decreasing the therapeutic effects of MSCs by decreasing their homing, differentiation, and paracrine effects [59-61]. The optimization of MSC culture conditions can serve as a key strategy to improve MSC functioning in vitro and in vivo, and RSV may serve as an effective agent for protecting MSCs from oxidative stress (Table 2).

\section{The effects of RSV on MSC engraftment}

Although MSCs may form strategic niches in perivascular spaces in almost every region of the body, they migrate to sites of injury for inflammation suppression and wound healing after the detection of local and distant tissue damage $[68,69]$. However, the injection of MSCs through the blood vessels leads to the engraftment of MSCs into the lungs and the capillary beds of other tissues or organs, consequently decreasing the number of MSCs migrating to the target areas [70]. RSV pretreatment in a common bile duct ligation (CBDL) animal model improved the therapeutic effects of MSCs via the upregulation of SIRT1 and the downregulation of p53, accompanied by the upregulation of the homing of MSCs to the liver and a decrease in homing of MSCs to

Table 2 Various concentrations of RSV exert different effects on MSCs in vivo

\begin{tabular}{|c|c|c|c|c|c|c|c|}
\hline RSV dosage & $\begin{array}{l}\text { MSC } \\
\text { source }\end{array}$ & $\begin{array}{l}\text { MSC } \\
\text { dose }\end{array}$ & Injury/disease & Model & Mechanism & Effect & Reference \\
\hline 10 mg/kg & $\begin{array}{l}\text { Bone } \\
\text { marrow }\end{array}$ & $1 \times 10^{6}$ & CBDL & Rat & $\begin{array}{l}\text { Upregulate the level of SIRT1 } \\
\text { and downregulate the level } \\
\text { of p53, upregulate the } \\
\text { homing of MSCs to the liver, } \\
\text { and decrease the homing of } \\
\text { MSCs to the lung and spleen }\end{array}$ & Eliminate liver cirrhosis & [62] \\
\hline 100 mg/kg & $\begin{array}{l}\text { Bone } \\
\text { marrow }\end{array}$ & $1 \times 10^{6}$ & Partial hepatectomy & Rat & $\begin{array}{l}\text { Increase the homing of MSCs } \\
\text { to the liver }\end{array}$ & Enhance liver regeneration & [63] \\
\hline 200 mg/kg & $\begin{array}{l}\text { Umbilical } \\
\text { cord }\end{array}$ & $1 \times 10^{6}$ & $\begin{array}{l}\text { Transgenic Alzheimer's } \\
\text { disease mouse model }\end{array}$ & Mouse & $\begin{array}{l}\text { Increase the engraftment of } \\
\text { MSCs }\end{array}$ & $\begin{array}{l}\text { Improve learning and } \\
\text { memory, enhance } \\
\text { neurogenesis, and alleviate } \\
\text { neural apoptosis in the } \\
\text { hippocampus in an } \\
\text { Alzheimer's disease mouse } \\
\text { model }\end{array}$ & [64] \\
\hline 200 mg/kg & $\begin{array}{l}\text { Umbilical } \\
\text { cord }\end{array}$ & $1 \times 10^{6}$ & Alzheimer's disease & Mouse & $\begin{array}{l}\text { Increase the expression of } \\
\text { hippocampal SIRT1, PCNA, } \\
\text { p53, ac-p53, p21, and p16 }\end{array}$ & $\begin{array}{l}\text { Increase the neurogenesis of } \\
\text { MSCs }\end{array}$ & [64] \\
\hline 100 mg/kg & $\begin{array}{l}\text { Adipose } \\
\text { tissue }\end{array}$ & $\begin{array}{l}2 \times \\
10^{6} / \mathrm{kg}\end{array}$ & $\begin{array}{l}\text { Doxorubicin-induced } \\
\text { injury }\end{array}$ & Rat & $\begin{array}{l}\text { Enhance the cardiogenic } \\
\text { differentiation and paracrine } \\
\text { effects of MSCs }\end{array}$ & $\begin{array}{l}\text { Prevent doxorubicin-induced } \\
\text { cardiomyopathy }\end{array}$ & [65] \\
\hline $\begin{array}{l}20 \mu \mathrm{M} \\
\text { (pretreatment) }\end{array}$ & $\begin{array}{l}\text { Umbilical } \\
\text { cord }\end{array}$ & $1 \times 10^{6}$ & Cisplatin-induced injury & Rat & $\begin{array}{l}\text { Upregulate the secretion } \\
\text { of PDGF-DD and increase } \\
\text { the phosphorylation of ERK }\end{array}$ & $\begin{array}{l}\text { Downregulate the apoptosis } \\
\text { of renal tubular cells, } \\
\text { upregulate the angiogenesis } \\
\text { of endothelial cells, and } \\
\text { decrease kidney injury }\end{array}$ & [66] \\
\hline 30 mg/kg & $\begin{array}{l}\text { Bone } \\
\text { marrow }\end{array}$ & $\begin{array}{l}1.5 \times \\
10^{6}\end{array}$ & $\begin{array}{l}\text { Mycobacterium tuberculosis } \\
\text { H37Ra and pertussis toxin } \\
\text { injury }\end{array}$ & Mouse & $\begin{array}{l}\text { Suppress the release of } \\
\text { proinflammatory cytokines } \\
\text { (IFN- } \gamma \text { and TNF-a) and } \\
\text { increase the release of anti- } \\
\text { inflammatory cytokines (IL-4 } \\
\text { and IL-10) }\end{array}$ & $\begin{array}{l}\text { Reduce the clinical scores of } \\
\text { patients with autoimmune } \\
\text { encephalomyelitis }\end{array}$ & [67] \\
\hline
\end{tabular}


the lung and spleen [62]. In rats with partial hepatectomy, RSV significantly increased the homing of MSCs to the liver and enhanced liver regeneration [63]. RSV also increased the engraftment of MSCs for the repair of hippocampal injuries in an Alzheimer's disease mouse model, thus improving learning and memory, enhancing neurogenesis, and alleviating neural apoptosis [64].

\section{The effect of RSV on differentiation in vivo}

Various dosages of RSV (1, 5, and $10 \mathrm{mg} / \mathrm{kg})$ significantly decreased myocardial lesions by increasing myocardial AKT expression and decreasing caspase- 3 activity during carbon monoxide-induced cardiotoxicity in rats in a dose-dependent manner [71]. RSV-pretreated MSCs showed increased proliferation and demonstrated enhanced cardiac remodeling capacity in diabetic cardiomyopathy via the attenuation of secreted frizzled-related protein-mediated fibrosis and the $\mathrm{Wnt} / \beta$-catenin pathway [72]. The combination of RSV exposure and MSC transplantation successfully prevented doxorubicininduced cardiomyopathy in rats via enhancing the cardiogenic differentiation and the paracrine effects of MSCs [65]. Wang et al. demonstrated that RSV increased the neurogenesis of MSCs by increasing the expression of hippocampal SIRT1, PCNA, p53, ac-p53, p21, and p16 in the hippocampus in an Alzheimer's disease mouse model [64]. A concentration of $20 \mu \mathrm{M}$ RSV upregulated the secretion of platelet-derived growth factor-DD (PDGF-DD) and increased the phosphorylation of ERK, thus downregulating the apoptosis of renal tubular cells. In addition, the release of the cytokine PDGF-DD upregulated the angiogenesis of endothelial cells; thus, the administration of RSV served as a novel strategy for enhancing the therapeutic efficacy of MSCs in cisplatin-induced kidney injury [66].

\section{The effect of RSV on paracrine mechanisms}

Interestingly, apart from the engraftment and differentiation of MSCs in vivo, initial preclinical animal models of inflammatory conditions suggested that MSCs protected against tissue injury via various paracrine mechanisms. MSCs exert paracrine effects via the release of multiple immunomodulatory factors via microvesicles, microRNAs, exosomes, and mitochondrial transfer [73]. RSV significantly decreased the expression of TNF $\alpha$ induced inflammatory cytokines, including IL-6 and IL8 , in MSCs after the activation of autophagy and the inhibition of the JNK signaling cascade [74]. In addition, the combination of RSV exposure and MSC transplantation significantly reduced the clinical scores of patients with autoimmune encephalomyelitis via suppressing the release of proinflammatory cytokines (IFN- $\gamma$ and TNF$\alpha)$ and increasing the release of anti-inflammatory cytokines (IL-4 and IL-10) [67].

\section{Conclusion}

RSV participates in regulating the survival, self-renewal, and multipotency of MSCs in vitro prior to MSC therapy. However, the concentration, time of administration, and duration of RSV pretreatment will influence the effects of RSV on MSCs in vitro and in vivo. We believe that further studies should focus on the therapeutic effects of RSV and MSC transplantation on diseases of the organs in addition to the liver, brain, heart, and kidney. On the other hand, although there are multiple RSV derivatives, including methoxylated, hydroxylated, and halogenated forms, that protect against multiple diseases, the application of RSV derivatives to MSCbased regeneration has been subject to little study; thus, it is necessary to investigate the protective effects of RSV derivatives in future studies. Furthermore, although RSV is safe and has been tolerated at dosages of up to $5 \mathrm{~g}$ /day without major side effects in long-term clinical trials [22, 75], the intake of $2.5 \mathrm{~g}$ or more per day of RSV may produce side effects such as nausea, vomiting, diarrhea, and liver dysfunction in patients with nonalcoholic fatty liver disease [76]. Therefore, the side effects of RSV may vary in sick patients; thus, we conclude that RSV is relatively safe for clinical application. It is worth noting that RSV will lose its bioactivity in vivo after oral or transvenous administration; thus, new biomaterials that can greatly improve the bioactivity or release of RSV will certainly contribute to MSC-based regenerative medicine.

\section{Abbreviations}

MSCs: Mesenchymal stromal cells; RSV: Resveratrol; ROS: Reactive oxygen species; RNS: Reactive nitrogen species; ERK1/2: Extracellular signal-regulated kinase 1/2; MICOS: Mitochondrial contact site and cristae organizing system; CSE: Cigarette smoke extract; CREB: Element-binding protein;

ALS: Amyotrophic lateral sclerosis; CBDL: Common bile duct ligation; PDGFDD: Platelet-derived growth factor-DD

\section{Acknowledgements}

Not applicable.

\section{Authors' contributions}

$\mathrm{CH}$ drafted and revised the manuscript. $\mathrm{LL}$ contributed to the manuscript conception. CH and LL provided financial support for the study. Both authors have read and approved the final manuscript.

\section{Funding}

This work was supported by the National Natural Science Foundation of China (No. 81700553), Stem Cell and Translational Research, the National Key Research and Development Program of China (No. 2016YFA0101001), and the Postdoctoral Research Foundation of China (No. 2017 M183789).

\section{Availability of data and materials}

All data are included in this published article.

Ethics approval and consent to participate Not applicable.

\section{Consent for publication}

Not applicable.

\section{Competing interests}

The authors declare that they have no competing interests. 
Received: 22 July 2019 Revised: 28 August 2019

Accepted: 9 September 2019 Published online: 17 October 2019

\section{References}

1. Dominici M, Le Blanc K, Mueller I, Slaper-Cortenbach I, Marini F, Krause D, Deans R, Keating A, Prockop D, Horwitz E. Minimal criteria for defining multipotent mesenchymal stromal cells. The international society for cellular therapy position statement. Cytotherapy. 2006:8(4):315-7. https://doi.org/10. 1080/14653240600855905.

2. Salem HK, Thiemermann C. Mesenchymal stromal cells: current understanding and clinical status. Stem Cells (Dayton, Ohio). 2010;28(3):58596. https://doi.org/10.1002/stem.269.

3. Eschenhagen T, Bolli R, Braun T, Field LJ, Fleischmann BK, Frisen J, Giacca M, Hare JM, Houser S, Lee RT, et al. Cardiomyocyte regeneration: a consensus statement. Circulation. 2017;136(7):680-6. https://doi.org/10.1161/ circulationaha.117.029343.

4. Faiella W, Atoui R. Immunotolerant properties of mesenchymal stem cells: updated review. Stem Cells Int. 2016;2016:1859567. https://doi.org/10.1155/ 2016/1859567

5. Bernardo ME, Fibbe WE. Mesenchymal stromal cells: sensors and switchers of inflammation. Cell Stem Cell. 2013;13(4):392-402. https://doi.org/10.1016/ j.stem.2013.09.006

6. Najar M, Raicevic G, Fayyad-Kazan H, Bron D, Toungouz M, Lagneaux L. Mesenchymal stromal cells and immunomodulation: a gathering of regulatory immune cells. Cytotherapy. 2016;18(2):160-71. https://doi.org/10. 1016/j.jcyt.2015.10.011

7. Mok PL, Leong CF, Cheong SK. Cellular mechanisms of emerging applications of mesenchymal stem cells. Malays J Pathol. 2013;35(1):17-32

8. Vauzour D. Dietary polyphenols as modulators of brain functions: biological actions and molecular mechanisms underpinning their beneficial effects. Oxidative Med Cell Longev. 2012;2012:914273. https:// doi.org/10.1155/2012/914273.

9. Burns J, Yokota T, Ashihara H, Lean ME, Crozier A. Plant foods and herbal sources of resveratrol. J Agric Food Chem. 2002;50(11):3337-40

10. Camont L, Cottart CH, Rhayem Y, Nivet-Antoine V, Djelidi R, Collin F, Beaudeux $J$, Bonnefont-Rousselot D. Simple spectrophotometric assessment of the trans-/cis-resveratrol ratio in aqueous solutions. Anal Chim Acta. 2009;634(1):121-8. https://doi.org/10.1016/j.aca.2008.12.003.

11. Stivala LA, Savio M, Carafoli F, Perucca P, Bianchi L, Maga G, Forti L, Pagnoni

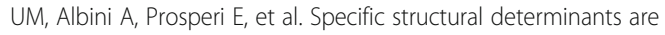
responsible for the antioxidant activity and the cell cycle effects of resveratrol. J Biol Chem. 2001;276(25):22586-94. https://doi.org/10.1074/jbc. M101846200.

12. Liu B, Ghosh S, Yang X, Zheng H, Liu X, Wang Z, Jin G, Zheng B, Kennedy $B K$, Suh $Y$, et al. Resveratrol rescues sirt1-dependent adult stem cell decline and alleviates progeroid features in laminopathy-based progeria. Cell Metab. 2012;16(6):738-50. https://doi.org/10.1016/j.cmet.2012.11.007.

13. Baur JA, Ungvari Z, Minor RK, Le Couteur DG, de Cabo R. Are sirtuins viable targets for improving healthspan and lifespan? Nat Rev Drug Discov. 2012; 11(6):443-61. https://doi.org/10.1038/nrd3738.

14. Nawaz W, Zhou Z, Deng S, Ma X, Ma X, Li C, Shu X. Therapeutic versatility of resveratrol derivatives. Nutrients. 2017;9(11). https://doi.org/ 10.3390/nu9111188.

15. Carrizzo A, Forte M, Damato A, Trimarco V, Salzano F, Bartolo M, Maciag A, Puca AA, Vecchione C. Antioxidant effects of resveratrol in cardiovascular, cerebral and metabolic diseases. Food Chem Toxicol. 2013;61:215-26. https://doi.org/10.1016/j.fct.2013.07.021.

16. Poulsen MM, Fjeldborg K, Ornstrup MJ, Kjaer TN, Nohr MK, Pedersen SB. Resveratrol and inflammation: challenges in translating pre-clinical findings to improved patient outcomes. Biochim Biophys Acta. 2015; 1852(6):1124-36. https://doi.org/10.1016/j.bbadis.2014.12.024.

17. Yousef M, Vlachogiannis IA, Tsiani E. Effects of resveratrol against lung cancer: in vitro and in vivo studies. Nutrients. 2017:9(11). https://doi.org/10. 3390/nu9111231.

18. Amri A, Chaumeil JC, Sfar S, Charrueau C. Administration of resveratrol: what formulation solutions to bioavailability limitations? J Control Release. 2012 158(2):182-93. https://doi.org/10.1016/j.jconrel.2011.09.083.

19. Chauhan AS. Dendrimer nanotechnology for enhanced formulation and controlled delivery of resveratrol. Ann N Y Acad Sci. 2015:1348(1):134-40. https://doi.org/10.1111/nyas.12816.
20. Goldberg DM, Yan J, Soleas GJ. Absorption of three wine-related polyphenols in three different matrices by healthy subjects. Clin Biochem. 2003;36(1):79-87.

21. Walle T, Hsieh F, DeLegge MH, Oatis JE Jr, Walle UK. High absorption but very low bioavailability of oral resveratrol in humans. Drug Metab Dispos. 2004;32(12):1377-82. https://doi.org/10.1124/dmd.104.000885.

22. Patel KR, Scott E, Brown VA, Gescher AJ, Steward WP, Brown K. Clinical trials of resveratrol. Ann N Y Acad Sci. 2011;1215:161-9. https://doi.org/10.1111/j. $1749-66322010.05853 x$

23. Bitterman $\mathrm{J}$, Chung $J \mathrm{H}$. Metabolic effects of resveratrol: addressing the controversies. Cell Mol Life Sci. 2015;72(8):1473-88. https://doi.org/10.1007/ s00018-014-1808-8.

24. Walle T. Bioavailability of resveratrol. Ann N Y Acad Sci. 2011;1215:9-15. https://doi.org/10.1111/j.1749-6632.2010.05842.x.

25. Biasutto L, Zoratti M. Prodrugs of quercetin and resveratrol: a strategy under development. Curr Drug Metab. 2014;15(1):77-95.

26. Xiao Y, Chen H, Song C, Zeng X, Zheng Q, Zhang Y, Lei X, Zheng X. Pharmacological activities and structure-modification of resveratrol analogues. Die Pharmazie. 2015;70(12):765-71.

27. Mishra B, Patel BB, Tiwari S. Colloidal nanocarriers: a review on formulation technology, types and applications toward targeted drug delivery. Nanomed Nanotechnol Biol Med. 2010;6(1):9-24. https://doi.org/10.1016/j. nano.2009.04.008

28. Guo L, Peng Y, Yao J, Sui L, Gu A, Wang J. Anticancer activity and molecular mechanism of resveratrol-bovine serum albumin nanoparticles on subcutaneously implanted human primary ovarian carcinoma cells in nude mice. Cancer Biother Radiopharm. 2010;25(4):471-7. https://doi.org/10.1089/ cbr.2009.0724.

29. Frozza RL, Bernardi A, Paese K, Hoppe JB, da Silva T, Battastini AM, Pohlmann AR, Guterres SS, Salbego C. Characterization of trans-resveratrolloaded lipid-core nanocapsules and tissue distribution studies in rats. J Biomed Nanotechnol. 2010;6(6):694-703.

30. Sessa M, Tsao R, Liu R, Ferrari G, Donsi F. Evaluation of the stability and antioxidant activity of nanoencapsulated resveratrol during in vitro digestion. J Agric Food Chem. 2011;59(23):12352-60. https://doi.org/10. 1021/jf2031346.

31. Atanackovic M, Posa M, Heinle H, Gojkovic-Bukarica L, Cvejic J. Solubilization of resveratrol in micellar solutions of different bile acids. Colloids Surf B: Biointerfaces. 2009;72(1):148-54. https://doi.org/10.1016/j.colsurfb.2009.03.029.

32. Singh G, Pai RS. Optimized plga nanoparticle platform for orally dosed trans-resveratrol with enhanced bioavailability potential. Expert Opin Drug Deliv. 2014;11(5):647-59. https://doi.org/10.1517/17425247.2014.890588.

33. Chang CW, Wong CY, Wu YT, Hsu MC. Development of a solid dispersion system for improving the oral bioavailability of resveratrol in rats. Eur J Drug Metab Pharmacokinet. 2017:42(2):239-49. https://doi.org/10.1007/s13318016-0339-0

34. Singh SK, Makadia V, Sharma S, Rashid M, Shahi S, Mishra PR, Wahajuddin M, Gayen JR. Preparation and in-vitro/in-vivo characterization of transresveratrol nanocrystals for oral administration. Drug Deliv Transl Res. 2017; 7(3):395-407. https://doi.org/10.1007/s13346-017-0362-y.

35. Colom H, Alfaras I, Maijo M, Juan ME, Planas JM. Population pharmacokinetic modeling of trans-resveratrol and its glucuronide and sulfate conjugates after oral and intravenous administration in rats. Pharm Res. 2011;28(7):1606-21. https://doi.org/10.1007/s11095-011-0395-8.

36. Lee KA, Shim W, Paik MJ, Lee SC, Shin JY, Ahn YH, Park K, Kim JH, Choi S, Lee $\mathrm{G}$. Analysis of changes in the viability and gene expression profiles of human mesenchymal stromal cells over time. Cytotherapy. 2009;11(6):68897. https://doi.org/10.3109/14653240902974032.

37. Francois M, Copland IB, Yuan S, Romieu-Mourez R, Waller EK, Galipeau J. Cryopreserved mesenchymal stromal cells display impaired immunosuppressive properties as a result of heat-shock response and impaired interferon-gamma licensing. Cytotherapy. 2012;14(2):147-52. https://doi.org/10.3109/14653249.2011.623691

38. Choi JR, Pingquan-Murphy B, Wan Abas WA, Noor Azmi MA, Omar SZ, Chua $\mathrm{KH}$, Wan Safwani WK. Impact of low oxygen tension on stemness, proliferation and differentiation potential of human adipose-derived stem cells. Biochem Biophys Res Commun. 2014;448(2):218-24. https://doi.org/10. 1016/j.bbrc.2014.04.096.

39. Schive SW, Mirlashari MR, Hasvold G, Wang M, Josefsen D, Gullestad HP, Korsgren O, Foss A, Kvalheim G, Scholz H. Human adipose-derived mesenchymal stem cells respond to short-term hypoxia by secreting factors 
beneficial for human islets in vitro and potentiate antidiabetic effect in vivo. Cell Med. 2017;9(3):103-16. https://doi.org/10.3727/215517917×693401.

40. Han KH, Kim AK, Kim MH, Kim DH, Go HN, Kim DI. Enhancement of angiogenic effects by hypoxia-preconditioned human umbilical cordderived mesenchymal stem cells in a mouse model of hindlimb ischemia. Cell Biol Int. 2016;40(1):27-35. https://doi.org/10.1002/cbin.10519.

41. Fu Y, Wang Y, Du L, Xu C, Cao J, Fan T, Liu J, Su X, Fan S, Liu Q, et al. Resveratrol inhibits ionising irradiation-induced inflammation in mscs by activating sirt1 and limiting nlrp-3 inflammasome activation. Int J Mol Sci. 2013;14(7):14105-18. https://doi.org/10.3390/ijms140714105.

42. Yoon DS, Choi Y, Choi SM, Park KH, Lee JW. Different effects of resveratrol on early and late passage mesenchymal stem cells through beta-catenin regulation. Biochem Biophys Res Commun. 2015;467(4):1026-32. https://doi. org/10.1016/j.bbrc.2015.10.017.

43. Wang X, Ma S, Meng N, Yao N, Zhang K, Li Q, Zhang Y, Xing Q, Han K, Song $J$, et al. Resveratrol exerts dosage-dependent effects on the self-renewal and neural differentiation of huc-mscs. Mol Cells. 2016;39(5):418-25. https://doi. org/10.14348/molcells.2016.2345.

44. Kornienko JS, Smirnova IS, Pugovkina NA, Ivanova JS, Shilina MA, Grinchuk TM, Shatrova AN, Aksenov ND, Zenin W, Nikolsky NN, et al. High doses of synthetic antioxidants induce premature senescence in cultivated mesenchymal stem cells. Sci Rep. 2019;9(1):1296. https://doi.org/10.1038/ s41598-018-37972-y.

45. Song $L H$, Pan $W$, Yu YH, Quarles $L D$, Zhou HH, Xiao ZS. Resveratrol prevents CSA inhibition of proliferation and osteoblastic differentiation of mouse bone marrow-derived mesenchymal stem cells through an er/no/cgmp pathway. Toxicol In Vitro. 2006;20(6):915-22. https://doi.org/10.1016/j.tiv.2006.01.016.

46. Dai Z, Li Y, Quarles LD, Song T, Pan W, Zhou H, Xiao Z. Resveratrol enhances proliferation and osteoblastic differentiation in human mesenchymal stem cells via ER-dependent ERK1/2 activation. Phytomedicine. 2007;14(12):80614. https://doi.org/10.1016/j.phymed.2007.04.003.

47. Erdman CP, Dosier CR, Olivares-Navarrete R, Baile C, Guldberg RE, Schwartz $Z$, Boyan BD. Effects of resveratrol on enrichment of adipose-derived stem cells and their differentiation to osteoblasts in two-and three-dimensional cultures. J Tissue Eng Regen Med. 2012;6(Suppl 3):s34-46. https://doi.org/10. 1002/term.513.

48. Wang $\mathrm{CC}$, Wang $\mathrm{CH}$, Chen $\mathrm{HC}$, Cherng JH, Chang SJ, Wang YW, Chang A, Yeh JZ, Huang YH, Liu CC. Combination of resveratrol-containing collagen with adipose stem cells for craniofacial tissue-engineering applications. Int Wound J. 2018;15(4):660-72. https://doi.org/10.1111/iwj.12910.

49. Lv YJ, Yang Y, Sui BD, Hu CH, Zhao P, Liao L, Chen J, Zhang LQ, Yang TT, Zhang SF, et al. Resveratrol counteracts bone loss via mitofilin-mediated osteogenic improvement of mesenchymal stem cells in senescence-accelerated mice. Theranostics. 2018;8(9):2387-406. https://doi.org/10.7150/thno.23620.

50. Wang YJ, Zhao P, Sui BD, Liu N, Hu CH, Chen J, Zheng CX, Liu AQ, Xuan K, Pan YP, et al. Resveratrol enhances the functionality and improves the regeneration of mesenchymal stem cell aggregates. Exp Mol Med. 2018; 50(6):74. https://doi.org/10.1038/s12276-018-0109-y.

51. Sreekumar V, Aspera-Werz R, Ehnert S, Strobel J, Tendulkar G, Heid D, Schreiner A, Arnscheidt C, Nussler AK. Resveratrol protects primary cilia integrity of human mesenchymal stem cells from cigarette smoke to improve osteogenic differentiation in vitro. Arch Toxicol. 2018;92(4):1525-38. https://doi.org/10.1007/s00204-017-2149-9.

52. Caldarelli I, Speranza MC, Bencivenga D, Tramontano A, Borgia A, Pirozzi AV, Perrotta S, Oliva A, Della Ragione F, Borriello A. Resveratrol mimics insulin activity in the adipogenic commitment of human bone marrow mesenchymal stromal cells. Int J Biochem Cell Biol. 2015;60:60-72. https:// doi.org/10.1016/j.biocel.2014.12.011.

53. Joe IS, Jeong SG, Cho GW. Resveratrol-induced sirt1 activation promotes neuronal differentiation of human bone marrow mesenchymal stem cells. Neurosci Lett. 2015;584:97-102. https://doi.org/10.1016/..neulet.2014.10.024.

54. Jahan S, Singh S, Srivastava A, Kumar V, Kumar D, Pandey A, Rajpurohit CS, Purohit AR, Khanna VK, Pant AB. Pka-gsk3beta and beta-catenin signaling play a critical role in trans-resveratrol mediated neuronal differentiation in human cord blood stem cells. Mol Neurobiol. 2018;55(4):2828-39. https:// doi.org/10.1007/s12035-017-0539-x.

55. Geng YW, Zhang Z, Liu MY, Hu WP. Differentiation of human dental pulp stem cells into neuronal by resveratrol. Cell Biol Int. 2017;41(12):1391-8. https://doi.org/10.1002/cbin.10835.

56. Guo L, Wang L, Wang L, Yun-Peng S, Zhou JJ, Zhao Z, Li DP. Resveratrol induces differentiation of human umbilical cord mesenchymal stem cells into neuron-like cells. Stem Cells Int. 2017;2017:1651325. https://doi.org/10. 1155/2017/1651325

57. Yun YC, Jeong SG, Kim SH, Cho GW. Reduced sirtuin 1/adenosine monophosphate-activated protein kinase in amyotrophic lateral sclerosis patient-derived mesenchymal stem cells can be restored by resveratrol. J Tissue Eng Regen Med. 2019;13(1):110-5. https://doi.org/10.1002/term.2776.

58. Jahan S, Kumar D, Singh S, Kumar V, Srivastava A, Pandey A, Rajpurohit CS, Khanna VK, Pant AB. Resveratrol prevents the cellular damages induced by monocrotophos via PI3K signaling pathway in human cord blood mesenchymal stem cells. Mol Neurobiol. 2018;55(11):8278-92. https://doi. org/10.1007/s12035-018-0986-z.

59. Robey TE, Saiget MK, Reinecke H, Murry CE. Systems approaches to preventing transplanted cell death in cardiac repair. J Mol Cell Cardiol. 2008; 45(4):567-81. https://doi.org/10.1016/j.yjmcc.2008.03.009.

60. Majzunova M, Dovinova I, Barancik M, Chan JY. Redox signaling in pathophysiology of hypertension. J Biomed Sci. 2013;20:69. https://doi.org/ 10.1186/1423-0127-20-69.

61. Sart S, Ma T, Li Y. Preconditioning stem cells for in vivo delivery. BioResearch Open Access. 2014;3(4):137-49. https://doi.org/10.1089/biores.2014.0012.

62. Hajinejad M, Pasbakhsh P, Omidi A, Mortezaee K, Nekoonam S, Mahmoudi R, Kashani IR. Resveratrol pretreatment enhanced homing of SDF-1apreconditioned bone marrow-derived mesenchymal stem cells in a rat model of liver cirrhosis. J Cell Biochem. 2018;119(3):2939-50. https://doi.org/ 10.1002/jcb.26500

63. Okay E, Simsek T, Subasi C, Gunes A, Duruksu G, Gurbuz Y, Gacar G, Karaoz E. Cross effects of resveratrol and mesenchymal stem cells on liver regeneration and homing in partially hepatectomized rats. Stem Cell Rev. 2015;11(2):322-31. https://doi.org/10.1007/s12015-014-9572-6.

64. Wang X, Ma S, Yang B, Huang T, Meng N, Xu L, Xing Q, Zhang Y, Zhang K, Li Q, et al. Resveratrol promotes hUC-MSCs engraftment and neural repair in a mouse model of Alzheimer's disease. Behav Brain Res. 2018;339:297304. https://doi.org/10.1016/j.bbr.2017.10.032.

65. Pinarli FA, Turan NN, Pinarli FG, Okur A, Sonmez D, Ulus T, Oguz A, Karadeniz C, Delibasi T. Resveratrol and adipose-derived mesenchymal stem cells are effective in the prevention and treatment of doxorubicin cardiotoxicity in rats. Pediatr Hematol Oncol. 2013;30(3):226-38. https://doi. org/10.3109/08880018.2012.762962.

66. Zhang R, Yin L, Zhang B, Shi H, Sun Y, Ji C, Chen J, Wu P, Zhang L, Xu W, et al. Resveratrol improves human umbilical cord-derived mesenchymal stem cells repair for cisplatin-induced acute kidney injury. Cell Death Dis. 2018;9(10):965. https://doi.org/10.1038/s41419-018-0959-1 .

67. Wang D, Li SP, Fu JS, Bai L, Guo L. Resveratrol augments therapeutic efficiency of mouse bone marrow mesenchymal stem cell-based therapy in experimental autoimmune encephalomyelitis. Int J Dev Neurosci. 2016;49: 60-6. https://doi.org/10.1016/j.jijdevneu.2016.01.005.

68. Shi Y, Hu G, Su J, Li W, Chen Q, Shou P, Xu C, Chen X, Huang Y, Zhu Z, et al. Mesenchymal stem cells: a new strategy for immunosuppression and tissue repair. Cell Res. 2010;20(5):510-8. https://doi.org/10.1038/cr.2010.44.

69. Kolf CM, Cho E, Tuan RS. Mesenchymal stromal cells. Biology of adult mesenchymal stem cells: regulation of niche, self-renewal and differentiation. Arthritis Res Therapy. 2007;9(1):204. https://doi.org/10.1186/ar2116.

70. Chen D, Li Q, Meng Z, Guo L, Tang Y, Liu Z, Yin S, Qin W, Yuan Z, Zhang X, et al. Bright polymer dots tracking stem cell engraftment and migration to injured mouse liver. Theranostics. 2017;7(7):1820-34. https://doi.org/10.7150/ thno.18614.

71. Hashemzaei M, Barani AK, Iranshahi M, Rezaee R, Tsarouhas K, Tsatsakis AM, Wilks MF, Tabrizian K. Effects of resveratrol on carbon monoxide-induced cardiotoxicity in rats. Environ Toxicol Pharmacol. 2016;46:110-5. https://doi. org/10.1016/j.etap.2016.07.010.

72. ShamsEldeen AM, Ashour H, Shoukry HS, Fadel M, Kamar SS, Aabdelbaset M Rashed LA, Ammar HI. Combined treatment with systemic resveratrol and resveratrol preconditioned mesenchymal stem cells, maximizes antifibrotic action in diabetic cardiomyopathy. J Cell Physiol. 2019;234(7):10942-63. https://doi.org/10.1002/jcp.27947.

73. Liang X, Ding Y, Zhang Y, Tse HF, Lian Q. Paracrine mechanisms of mesenchymal stem cell-based therapy: current status and perspectives. Cell Transplant. 2014;23(9):1045-59. https://doi.org/10.3727/096368913×667709.

74. Wang FM, Hu Z, Liu X, Feng JQ, Augsburger RA, Gutmann JL, Glickman GN. Resveratrol represses tumor necrosis factor a/c-Jun N-terminal kinase signaling via autophagy in human dental pulp stem cells. Arch Oral Biol. 2019;97:116-21. https://doi.org/10.1016/j.archoralbio.2018.10.020. 
75. Tome-Carneiro J, Gonzalvez M, Larrosa M, Yanez-Gascon MJ, Garcia-Almagro FJ, Ruiz-Ros JA, Tomas-Barberan FA, Garcia-Conesa MT, Espin JC. Grape resveratrol increases serum adiponectin and downregulates inflammatory genes in peripheral blood mononuclear cells: a triple-blind, placebocontrolled, one-year clinical trial in patients with stable coronary artery disease. Cardiovasc Drugs Ther. 2013;27(1):37-48. https://doi.org/10.1007/ s10557-012-6427-8.

76. Brown VA, Patel KR, Viskaduraki M, Crowell JA, Perloff M, Booth TD, Vasilinin G, Sen A, Schinas AM, Piccirilli G, et al. Repeat dose study of the cancer chemopreventive agent resveratrol in healthy volunteers: safety, pharmacokinetics, and effect on the insulin-like growth factor axis. Cancer Res. 2010;70(22):9003-11. https://doi.org/10.1158/0008-5472.can-10-2364.

\section{Publisher's Note}

Springer Nature remains neutral with regard to jurisdictional claims in published maps and institutional affiliations. 